\title{
UPAYA MENGEMBANGKAN KEMAMPUAN BAHASA DALAM MENYUSUN KALIMAT SEDERHANA PADA STRUKTUR LENGKAP MELALUI MEDIA VISUAL PADA ANAK KELOMPOK B TK PERMATA HATI MARTAPURA KABUPATEN BANJAR
}

\author{
Oleh: Nurul Fatmawati \\ (Mahasiswa S1 PG PAUD Universitas lambung Mangkurat)
}

\begin{abstract}
Abstrak
Permasalahan dalam penelitian ini adalah rendahnya hasil pengembangan kemampuan bahasa dalam menyusun kalimat sederhana pada struktur lengkap pada anak Kelompok B TK Permata Hati Martapura Kabupaten Banjar yang disebabkan siswa sulit memahami materi serta kurangnya penggunaan alat peraga dan tanpa adanya pengalaman langsung pada saat proses pembelajaran yang hanya berpatokan pada buku paket atau penjelasan guru saja. Hal ini terbukti Hal ini terbukti dari 14 orang anak, hanya 6 anak atau $42 \%$ yang berkembang sesuai harapan, sedangkan 8 anak atau $58 \%$ masih dikatagorikan belum berkembang. Untuk memperbaiki pengembangan kemampuan bahasa anak maka digunakan media visual. Tujuan pelaksanaan penelitian adalah untuk mengetahui aktivitas guru saat melaksanakan pembelajaran, aktivitas anak saat mengikuti pembelajaran, dan hasil pengembangan kemampuan bahasa dalam menyusun kalimat sederhana pada struktur lengkap pada anak Kelompok B TK Permata Hati Martapura Kabupaten Banjar.

Metode penelitian ini menggunakan Penelitian Tindakan Kelas (PTK) yang dilaksanakan sebanyak 2 siklus, siklus I dan siklus II masing-masing dua kali pertemuan. Penelitian ini mengambil setting di TK Permata Hati Martapura Kabupaten Banjar pada semester I tahun pelajaran 2014/2015. Subjek penelitian ini adalah seluruh anak di kelompok B yang berjumlah 14 orang. Data diolah dengan interpretasi, distribusi frekuensi, dan persentase. Instrumen pengumpulan data melalui observasi guru, observasi anak dan hasil pengembangan anak selama proses pembelajaran.

Hasil penelitian menunjukkan aktivitas guru dalam pelaksanaan pengembangan kemampuan bahasa anak melalui media visual dalam menyusun kalimat sederhana pada struktur lengkap aktivitas guru terlaksana dengan katagori sangat baik. Aktivitas anak pada siklus I dengan persentase $53 \%$ katagori aktif mengalami peningkatan menjadi $96 \%$ katagori sangat aktif. Hasil pengembangan kemampuan bahasa berkembang sesuai harapan dari siklus I $43 \%$ menjadi $100 \%$ pada siklus II.

Berdasarkan hasil penelitian dapat disimpulkan bahwa hasil pengembangan kemampuan bahasa pada materi menyusun kalimat sederhana pada struktur lengkap melalui media visual pada anak Kelompok B TK Permata Hati Martapura Kabupaten Banjar berkembang dengan signifikan dan hipotesa diterima.

Saran untuk guru, Taman Kanak-kanak dan peneliti, bahwa media visual dapat dijadikan salah satu alternatif yang dapat digunakan untuk pengembangan kemampuan bahasa anak.
\end{abstract}

Kata kunci: Kemampuan Bahasa, Media Visual, Menyusun Kalimat Sederhana 


\section{Pendahuluan}

Pendidikan TK merupakan salah satu bentuk pendidikan anak usia dini yaitu anak yang berusia empat dan enam tahun. Pendidikan TK memiliki peranan penting untuk mengembangkan kepribadian anak serta mempersiapkan mereka untuk memasuki jenjang pendidikan selanjutnya. Menurut pendapat Bredecamp (1997) dalam Masitoh (2005: 1.5) menyatakan bahwa pendidikan anak usia dini mencakup berbagai program yang melayani anak dari lahir sampai dengan delapan tahun yang dirancang untuk meningkatkan perkembangan intelektual, sosial, emosi, bahasa, dan fisik anak.

Secara umum dalam kehidupan sehari-hari bila ditinjau dari segi media atau sarana yang digunakan untuk menghasilkan bahasa, kita menggunakan dua ragam bahasa, yaitu ragam bahasa lisan dan ragam bahasa tulisan. Ragam lisan atau disebut dengan kemampuan bahasa lisan merupakan kemampuan berbahasa pertama yang dikuasai anak. Secara alamiah setiap anak yang normal belajar berbahasa melalui proses mendengarkan. Melalui proses tersebut akhirnya anak belajar berbicara.

Perkembangan bahasa memperlihatkan berbagai prinsip yang juga menjadi karakteristik dari aspek perkembangan yang lain, dan aspek tumbuh pada pihak lain. Meliputi ketermunculan dari respon baru dan penghalusan dari bentuk-bentuk lama, mencakup pembaharuan (Semiawan, 2008: 4).
Perkembangan bahasa sebagai salah satu dari kemampuan dasar yang harus dimiliki oleh anak, terdiri dari beberapa tahapan sesuai dengan usia dini dan karakteristik perkembangannya. Perkembangan adalah suatu perubahan yang berlangsung,seumur hidup dan dipengaruhi oleh berbagai faktor yang saling berinteraksi seperti biologis, kognitif, dan sosial emosional. Menurut santrock bahasa adalah suatu sistem simbol untuk berkomunikasi meliputi ponologi (unit suara), morfologi (unit arti), sintaksis (tata bahasa), semantic (variasi arti) dan pragmatic (penggunaan) bahasa. Dengan bahasa, anak dapat berkomunikasikan maksud, tujuan, pemikiran, maupun perasaannya pada orang lain (Dhieni,2005: 3.1)

Anak usia 4-5 tahun rata-rata dapat mengungkapkan 900-1000 kosa kata yang berbeda. Mereka menggunakan 4-5 kata dalam suatu kalimat yang dapat berbentuk kalimat pernyataan, negative, tanya dan perintah. Owens mengemukakan bahwa anak usia dini tersebut memperkaya kosa katanya melalui pengulangan. Mereka sering mengulangi kosa kata yang baru dan urut sekalipun mungkin belum memahami artinya. Dalam mengembangkan kosa kata tersebut, anak menggunakan fast mapping yaitu suatu proses dimana anak menyerap arti kata baru setelah mendengarkan sekali atau dua kali dalam percakapan. Pada masa kanak-kanak inilah anak mulai mengkombinasikan suku kata 
menjadi kata,dan kata menjadi kalimat. (Dhieni,2011: 3.1).

Keterampilan mendengarkan merupakan keterampilan menerima dan memahami isi atau pesan suatu ujaran yang disampaikan penutur dengan bahasa lisan. Keterampilan mendengarkan diperoleh seorang anak sebelum keterampilan berbicara. Dalam hal ini mendengarkan dan mengulang kalimat yang lebih kompleks mempunyai satu kesatuan satu sama lain. Sebelum melakukan kegiatan menyusun kalimat terlebih dahulu melakukan kegiatan sesuai dengan apa yang sudah di lihat.

Pengembangan bahasa pada anak usia TK perlu mendapat perhatian penting, mengingat bahwa bahasa merupakan pusat dari pengembangan aspek-aspek yang lain. Menjadi kewajiban orang tua dan guru untuk melakukan berbagai usaha dalam pengembangan keterampilan berbahasa anak melalui berbagai kegiatan didalam atau di luar kelas, dan kegiatan permainan bahasa yang menyenangkan anak (Dhieni, 2011: 9.1).

Pada kenyataannya, pembelajaran bahasa dalam menyusun kalimat sederhana dalam struktur lengkap masih sulit terutama bagi anak usia dini, rendahnya minat anak didik belajar bahasa (keaksaraan) dengan benda-benda yang ada di lingkungan, lebih menyukai pembelajaran mewarnai, motorik kasar/halus dan bermain di luar. Hal ini ditandai dengan kondisi dari 14 orang anak kelompok B TK
Permata Hati Martapura Kabupaten Banjar hanya terdapat 6 anak atau $42 \%$ yang paham atau berkembang sesuai harapan dalam menyusun kalimat sederhana dalam struktur lengkap, sedangkan yang 8 orang anak atau 58 $\%$ masih dikategorikan mulai berkembang. Hal ini disebabkan oleh beberapa faktor permasalahan baik dari guru, anak maupun sumber belajar sebagai pendukungnya, karena masih kurangnya kemampuan dan peran dari orang tua serta guru dalam mengembangkan bahasa dalam menyusun kalimat sederhana dalam struktur lengkap, model pembelajaran yang kurang menarik minat, metode yang digunakan adalah metode ceramah kegiatan pembelajaran berpusat pada guru, media yang digunakan kurang menarik dan anak pasif mendengarkan penjelasan guru sehingga seharusnya menyenangkan menjadi kurang menarik minat anak dan anak asyik dengan kegiatannya sendiri.

Oleh karena itu untuk memecahkan permasalahan tersebut diperlukan penelitian tindakan kelas sebagai upaya perbaikan pelaksanaan upaya mengembangkan bahasa dalam menyusun kalimat sederhana dalam struktur lengkap melalui media visual. Media visual terdiri dari gambar diam/gambar mati berupa foto asli atau bukan lukisan, media grafis (media pandang dua dimensi) berupa gambar dan tulisan, media model tiga dimensi (tiruan dari beberapa objek nyata), media realita benda sesungguhnya: misalkan ayam, 
ayam sesungguhnya. Pembelajaran dengan media visual di rancang yang bertujuan untuk mendorong siswa untuk berani mengungkapkan pendapat dan juga mengajak anak untuk berkonsentrasi dengan baik menggunakan indra penglihatan dan kognitifnya.

\section{Kajian Teori}

\section{Karakteristik Perkembangan Anak Usia} Dini

Anak usia dini memiliki karakteristik yang khas. Menurut Hartati (Aisyah, 2007: 14) beberapa karakteristik anak usia dini tersebut adalah sebagai berikut.

a. Memiliki rasa ingin tahu yang besar Anak usia dini sangat tertarik dengan dunia sekitarnya. Dia ingin mengetahui segala sesuatu yang terjadi di sekelilingnya.

b. Merupakan pribadi yang unik

Meskipun banyak terdapat kesamaan dalam pola umum perkembangan, setiap anak meskipun kembar memiliki keunikan masing-masing, misalnya dalam hal gaya belajar, minat, dan latar belakang keluarga.

c. Suka berfantasi dan berintegrasi

Anak usia dini sangat suka membayangkan dan mengembangkan berbagai hal jauh melampaui kondisi nyata.

d. Masa paling potensial untuk belajar Anak usia dini sering juga disebut dengan istilah golden age atau usia emas, karena pada rentang usia ini anak mengalami pertumbuhan dan perkembangan yang sangat pesat pada berbagai aspek.

e. Menunjukkan sikap egosentris Egosentris artinya berpusat pada aku, maksudnya bahwa anak usia dini pada umumnya hanya memahami sesuatu dari sudut pandangnya sendiri, bukan sudut pandang orang lain.

f. Memiliki rentang daya konsentrasi yang pendek

Seringkali kita saksikan bahwa anak usia dini cepat sekali berpindah dari suatu kegiatan ke kegiatan yang lain. Anak usia dini memang mempunyai rentang perhatian yang sangat pendek sehingga perhatiannya mudah teralihkan pada kegiatan lain.

g. Sebagai bagian dari makhluk sosial Anak usia dini mulai suka bergaul dan bermain dengan teman sebayanya. Ia mulai belajar berbagi, mengalah, dan antri menunggu giliran saat bermain dengan teman-temannya.

\section{Pengembangan Bahasa Anak Usia Dini}

Bahasa adalah segala bentuk komunikasi di mana pikiran dan perasaan seseorang disimbolisasikan agar dapat menyampaikan arti kepada orang lain. Oleh karena tiu, perkembangan bahasa dimulai dari tangisan pertama sampai anak mampu bertutur kata. 
Perkembangan bahasa terbagi menjadi dua periode, yaitu, periode Prelinguistik dan periode Linguistik. Periode Linguistik inilah anak mulai mengucapkan kata-kata pertama.

Bahasa adalah suatu sistem simbol untuk berkomunikasi yang meliputi fonologi (unit suara), marfologi (unit arti), sintaksis (tata bahasa) semantik (variasi arti), dan pragmatic (penggunaan) bahasa. Dengan bahasa, anak dapat mengkomunikasikan maksud, tujuan, pemikiran, maupun perasaannya pada orang lain. (Dhieni, 2005: 5.1).

Menurut Sumantri (2008: 2.30-2.31) periode linguistic terbagi dalam tiga fase besar, yaitu:

\section{a. Fase satu kata atau Holofrase}

Pada fase ini anak mempergunakan satu kata untuk menyatakan pikiran yang kompleks, baik berupa keinginan, perasaan atau temuannya tanpa perbedaan yang jelas. Pada umumnya kata pertama yang diucapkan oleh anak adalah kata benda, setelah beberapa waktu barulah disusul dengan kata kerja.

\section{b. Fase lebih dari satu kata}

Fase dua kata muncul pada anak berusia sekitar 18 bulan. Pada fase ini anak sudah dapat membuat kalimat sederhana yang terdiri dari dua kata. Pada periode ini bahasa yang digunakan oleh anak tidak lagi egosentris, dari dan untuk dirinya. Orang tua mulai melakukan Tanya jawab dengan anak secara sederhana. Anak pun mulai dapat bercerita dengan kalimat-kalimat sederhana.

\section{c. Fase diferensiasi}

Periode terakhir dari masa balita yang berlangsung antara usia dua setengah sampai lima tahun. Keterampilan anak dalam berbicara mulai lancer dan berkembang pesat. Dalam berbicara anak bukan saja menambah kosakatanya yang mengagumkan akan tetapi anak mulai mampu mengungkapkan kata demi kata sesuai dengan jenisnya, terutama dalam pemakaian kata benda dan kata kerja.

Seefelt dan Wasik (2008: 81) menyatakan bahwa imajinasi anak anak usia 5 tahun mulai berkembang, masih berfikir hal yang konkret, dapat melihat benda dari kategori yang berbeda, senang menyortir dan mengelompokan, pemahaman konsep meningkat, dan mengetahui tentang apa yang asli dan palsu. Dari kajian mengenai perkembangan kognitif anak diketahui bahwa unsur yang menonjol pada tahap preoperasional adalah mulai digunakanya bahasa simbolis yang berupa gambaran dan bahasa ucapan. Anak dapat berbicara tanpa dibatasi waktu sekarang dan dapat membicarakan satu hal bersama-sama. Dengan bahasa anak dapat mengenal bermacam benda dan mengetahui nama-nama benda yang dikenal melalui pendengaran dan penglihatanya. Perkembangan bahasa ini akan sangat memperlancar perkembangan kognitif anak.

Suyanto (2005: 161) mengatakan bahwa pengembangan bahasa untuk anak TK adalah 
untuk mengembangkan kemampuan berkomunikasi oral, mengenal huruf dan membaca, mendengar dan memahami perintah, menulis dan menggunakan literatur. Pembelajaran bahasa untuk anak usia dini diarahkan pada kemampuan berkomunikasi, baik secara lisan maupun tulisan (simbolis). Oleh karena itu, belajar bahasa sering dibagi menjadi dua bagian yaitu belajar bahasa untuk komunikasi dan belajar literasi, yaitu membaca dan menulis.

Menurut Bromley fungsi bahasa ada 5 macam yaitu :

1. Bahasa menjelaskan keinginan dan kebutuhan individu. Anak usia dini belajar kata-kata yang dapat keinginan dan kebutuhan dan keinginan utama mereka.

2. Bahasa dapat merubah dan mengontrol perilaku. Anak-anak bahwa mereka dapat mempengaruhi lingkungan dan mengarahkan perilaku orang dewasa dengan menggunakan bahasa.

3. Bahasa membantu perkembangan kognitif. Secara simbolik bahasa menjelaskan hal yang nyata dan tidak nyata. Melalui bahasa kita dapat mengingat kembali suatu informasi yang pernah diperoleh dan menghubungkannya dengan informasi yang baru.
4. Bahasa membantu mempererat interaksi dengan orang lain dan berperan untuk kesuksesan sosialisasi individu.

5. Bahasa mengekspresikan keunikan individu. Kita dapat mengemukakan pendapat dan perasan pribadi dengan cara yang berbeda dari orang lain.

Alat perkembangan yang dapat digunakan untuk perkembangan bahasa anak adalah sebagai berikut :

1. Benda-benda atau gambar-gambar yang ada di lingkungan anak

2. Benda dan gambar untuk alat intruksi guru

3. Alat permainan gambar, lotto, gambar berurutan

4. Alat tulis dan media kreativitas

5. Kumpulan buku cerita dan buku referensi untuk dibacakan kepada anak maupun untuk dipinjamkan

6. Kumpulan cerita pendek

7. Kumpulan gambar profesi yang dapat diperkenalkan anak atau yang sudah mereka ketahui

8. Kumpulan gambar, poster untuk berbagai macam tema sebagai konsep dasar yang perlu diketahui anak.

\section{Media Pembelajaran Visual}

Secara harfiah media berarti "perantara" antara sumber pesan dan menerima pesan. Media pembelajaran selalu terdiri dari 2 unsur penting yaitu unsur peralatan atau perangkat keras 
(hardware) dan unsur pesan yang dibawanya (massage/software).

Media berbasis visual (image atau perumpamaan) memegang peranan yang sangat penting dalam proses belajar. Media visual dapat memperlancar pemahaman dan memperkuat ingatan. Visual dapat pula menumbuhkan minat siswa dan dapat memberikan hubungan antara isi materi pelajaran dengan dunia nyata. Agar menjadi efektif, visual sebaiknya ditempatkan pada konteks yang bermakna dan siswa harus berinteraksi dengan visual (image) itu untuk meyakinkan terjadinya proses informasi. Yang termasuk dalam kelompok ini yaitu Gambar representasi, Diagram, Peta, Grafik, Overhead Projektor (OHP), Slide, dan Filmstrip.

Media visual disebut juga media pandang karena kita dapat menghayati media tersebut melalui penglihatan kita. Media visual dapat dibedakan atas dua jenis yaitu: media visual yang tidak diproyeksikan dan media media visual diproyeksikan.

Contohnya: (handware) benda kaca mata (massage/software) : pesan guna kacamata.

Nilai (fungsi) media pembelajaran:

1. Mengkonkretkan konsep-konsep yang abstrak

2. Menghadirkan objek-objek yang terlalu berbahaya atau sukar didapat dalam lingkungan belajar
3. Menampilkan objek yang terlalu besar

4. Memperlihatkan gerakan yang terlalu cepat (dengan slozo mition)

Media Visual dapat dilihat sebagai berikut:

1. Gambar diam/gambar mati (fotografi) : Foto asli atau bukan lukisan.

2. Media grafis (media pandang dua dimensi) berupa gambar dan tulisan

3. Media model tiga dimensi (tiruan dari beberapa objek nyata)

4. Media realita (benda sesungguhnya) : misalkan ayam, ayam sesungguhnya.

Peran guru dalam kegiatan ini adalah sebagai :

\section{Insprirator}

Sebagai inspirator guru dapat memberikan ilham yang baik bagi kemajuan pengembangan bahasa anak. Guru harus dapat menciptakan atau mengembangkan berbagai media, alat maupun metode-metode dalam pelaksana kegiatan.

\section{Motivator}

Sebagai motivator guru dapat mendorong anak agar lebih bersemangat dan aktif dalam belajar. Motivasi anak akan lebih efektif bila dilakukan dengan memperhatika kebutuhan anak.

\section{Fasilitator}

Sebagai fasilitator guru dapat menyediakan fasilitas yang memungkinkan dan memudahkan kegiatan belajar anak, menyediakan lingkungan belajar yang menyenangkan dan dapat membangkitkan 
anak untuk melakukan eksplorasi serta menyalurkan minat dan keinginannya secara aktif.

\section{Mediator}

Sebagai mediator guru dapat berperan sebagai penyedia media yang cocok untuk anak (Kumpul Blogger, 2010 : Online)

Kegiatan yang dilakukan guru ini merupakan upaya untuk menarik perhatian sehingga pada akhirnya dapat menciptakan keaktifan dan memotivasi anak dalam diskusi. Hal ini sejalan dengan pendapat Hamalik (1994;116), "Motivasi yang kuat erat hubungannya dengan peningkatan keaktifan anak yang dapat dilakukan dengan strategi pembelajaran tertentu dan motivasi belajar dapat ditujukan kearah kegiatan-kegiatan kreatif. Apabila motivasi yang dimiliki anak diberi berbagai tantangan akan tumbuh kegiatan kreatif".

\section{Metode Penelitian}

\section{Pendekatan Penelitian}

Pendekatan yang digunakan dalam penelitian ini adalah pendekatan kualitatif yaitu pendekatan yang berpedoman pada aktivitas siswa dalam upaya mengembangkan bahasa pada materi menjawab pertanyaan sederhana, sedangkan penelitian ini tergolong penelitian tindakan kelas (classroom action research) yang terdiri atas tahapan-tahapan perencanaan, pelaksanaan tindakan, observasi dan evaluasi, analisi dan refleksi.

\section{Setting Penelitian}

Penelitian ini dilaksanakan di Taman KanakKanak Permata Hati pada anak kelompok B yang terdiri dari 14 orang anak, 9 orang anak perempuan dan 5 orang anak laki-laki.

\section{Skenario Tindakan}

Penelitian tindakan kelas ini direncanakan terdiri dari dua siklus. Tiap siklus dilaksanakan dalam dua pertemuan. Tiap-tiap siklus direncanakan berkesinambungan, artinya proses dan hasil siklus 1 akan ditindak lanjuti dalam siklus 2. Prosedur penelitian tindakan kelas ini setiap siklus meliputi: (1) perencanaan (planing); (2) tindakan (acting); (3) observasi (observing); (4) evaluasi (evaluating); (5) refleksi (reflekting).

\section{Data dan Cara Pengumpulan Data}

Untuk memperoleh informasi yang valid dan realibel dari pelaksanaan penelitian tindakan ini, maka perlu kelengkapan data, kualitas alat pengumpul data dan ketepatan alat analisanya.

\section{Sumber Data}

Data tentang aktivitas guru dalam melaksanakan kegiatan pembelajaran dengan media visual dengan menggunakan lembar observasi.

Data tentang kegiatan anak dalam melakukan kegiatan menyusun kalimat sederhana pada 
struktur lengkap melalui media visual dengan mengunakan lembar observasi

\section{Cara Pengambilan Data}

1. Data aktifitas guru diambil melalui observasi tahapan-tahapan proses mengajar dikelas menggunakan media visual.

2. Data aktifitas anak diambil melalui observasi pada proses kegiatan pembelajaran menyusun kalimat sederhana pada struktur lengkap melalui media visual.

3. Data hasil pengembangan kemampuan bahasa anak melalui media visual dapat dilakukan dengan menggunakan lembar kerja siswa (LKS) dan LKK.

\section{Hasil Penelitian}

Pelaksanaan Tindakan Kelas Siklus I

\section{Pertemuan I}

\section{Hasil Observasi}

1. Aktivitas guru

Hasil Observasi Aktivitas Guru Siklus I Pertemuan 1

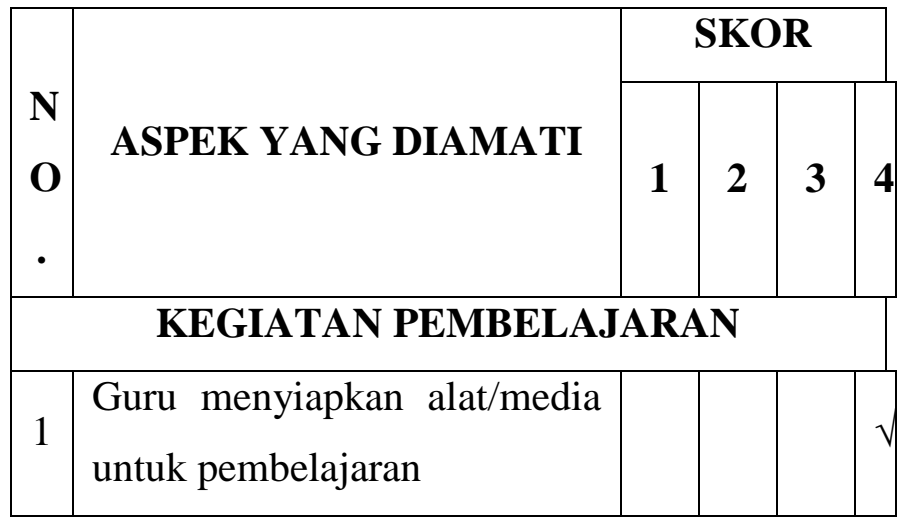

\begin{tabular}{|c|c|c|}
\hline 2 & $\begin{array}{l}\text { Guru menyampaikan tujuan } \\
\text { pembelajaran yang akan } \\
\text { dipelajari }\end{array}$ & $\sqrt{ }$ \\
\hline 3 & $\begin{array}{l}\text { Guru memperlihatkan gambar } \\
\text { serta kalimat dibawah gambar } \\
\text { lalu menempelkan di papan } \\
\text { tulis. }\end{array}$ & $\sqrt{ }$ \\
\hline 4 & $\begin{array}{l}\text { Guru menyampaikan tentang } \\
\text { makna dari gambar tersebut. }\end{array}$ & $\sqrt{ }$ \\
\hline 5 & $\begin{array}{l}\text { Guru meminta anak menyusun } \\
\text { kalimat sederhana pada } \\
\text { struktur lengkap yang kata- } \\
\text { katanya diacak. }\end{array}$ & $\sqrt{ }$ \\
\hline 6 & $\begin{array}{l}\text { Guru membagi anak menjadi } \\
\text { kelompok, masing-masing } \\
\text { kelompok bekerjasama dalam } \\
\text { menyusun kalimat pada } \\
\text { struktur lengkap }\end{array}$ & $\sqrt{ }$ \\
\hline & TOTAL SKOR & 19 \\
\hline & KRITERIA & $\begin{array}{c}\text { SANGAT } \\
\text { BAIK }\end{array}$ \\
\hline
\end{tabular}

2. Aktivitas anak

Anak belum terbiasa dengan model pembelajaran yang digunakan, sehingga mereka kurang tanggap terhadap aturan yang ada. Beberapa anak sudah berani maju kedepan tetapi dengan bujukan dan rayuan guru, anak sudah mau bekerjsama dalam kelompok namun hanya sebagian kecil anak saja, karena anak merasa malu dan canggung pada saat kegiatan berkelompok dilaksanakan dan anak sudah dapat menyusun kalimat sederhana dalam 
struktur lengkap tetapi hanya sebagian kecil anak saja. Hal ini menunjukkan bahwa aktivitas anak dalam kegiatan pembelajaran perlu ditingkatkan lagi pada pertemuan berikutnya agar keaktifan anak meningkat.

\section{Hasil pengembangan}

Hasil pengembangan bahasa dalam menyusun kalimat sederhana dalam struktur lengkap yaitu tidak ada anak yang mendapat * dengan persentase $0 \%, 8$ orang anak yang mendapat ** dengan persentase $57 \%$, tidak ada anak yang mendapat $* * *$, dan 6 anak yang mendapat **** persentase $43 \%$. Hasil belajar anak pada pertemuan 1 siklus I sebesar $43 \%$, hal ini berarti ketuntasan klasikal belum tercapai karena nilai ketuntasan kurang dari indikator keberhasilan yang ditetapkan yaitu $80 \%$. Sehingga perlunya pengembangan kemampuan bahasa anak dalam menyusun kalimat sederhana dalam struktur lengkap pada pertemuan berikutnya agar hasil pengembangan mencapai indikator yang ditetapkan

Pelaksanaan Tindakan Kelas Siklus I Pertemuan II

\section{Hasil Observasi}

1. Aktivitas guru

Hasil Aktivitas Pembelajaran Guru

\begin{tabular}{|c|c|c|c|c|c|}
\hline \multirow{2}{*}{ N } & \multirow{2}{*}{ ASPEK YANG DIAMATI } & \multicolumn{4}{|c|}{ SKOR } \\
\cline { 3 - 6 } & & 1 & 2 & 3 & 4 \\
\hline
\end{tabular}

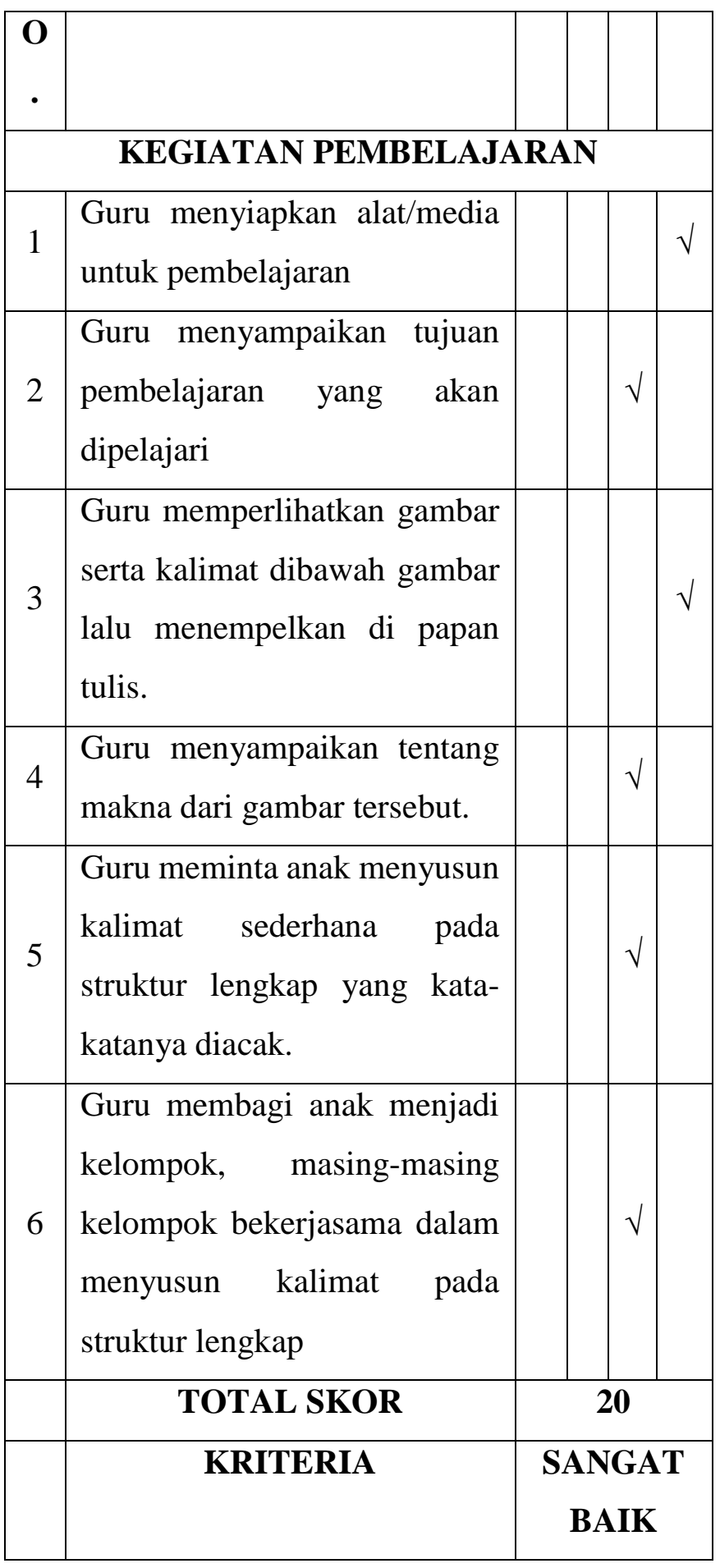

2. Aktivitas anak

Beberapa anak sudah berani maju kedepan tetapi masih dengan bujukan dan rayuan guru, anak sudah mau bekerjasama dalam kelompok namun hanya sebagian kecil anak saja, karena anak merasa malu dan canggung pada saat 
kegiatan berkelompok dilaksanakan dan anak sudah dapat menyusun kalimat sederhana dalam struktur lengkap tetapi masih ada dengan bimbingan guru. Hal ini menunjukkan bahwa aktivitas anak dalam kegiatan pembelajaran perlu ditingkatkan lagi pada pertemuan berikutnya agar keaktifan anak meningkat dan mencapai indikator yang ditetapkan. Rata-rata dari aktivitas semua kelompok mengalami peningkatan tetapi belum maksimal dalam aspek antusias melaksanakan tugas, keberanian maju ke depan kelas melakukan kegiatan, ketepatan dalam menyusun kalimat sederhana dalam struktur lengkap, dan kerjasama menyelesaikan tugas. Perbaikan-perbaikan yang akan dilakukan berlaku untuk semua kelompok dan semua aspek.

\section{Hasil pengembangan}

Hasil pengembangan bahasa dalam menyusun kalimat sederhana yaitu tidak ada anak yang mendapat $*$, anak yang mendapat $* *$ ada 7 orang anak persentase $50 \%$, tidak ada anak yang mendapat $* * *, 5$ orang anak mendapat **** dengan persentase $50 \%$. Melihat persentase keberhasilan ini, ternyata hasil kemampuan bahasa anak dalam menyusun kalimat sederhana di kelompok B TK Permata Hati yaitu $50 \%$, hal ini menunjukkan peningkatan hasil pengembangan bahasa tetapi masih di bawah indikator keberhasilan yang ditentukan yaitu $80 \%$.

\section{Refleksi Siklus I}

1. Aktivitas Guru
Aktivitas guru telah terlaksana sesuai dengan indikator keberhasilan tetapi masih ada indikator/aspek yang masih belum terlaksana dengan optimal yaitu pada aspek guru sudah menyampaikan tujuan pembelajaran, harus dengan suara yang lantang dan jelas agar anak memahami dan termotivasi untuk mendengarkan guru, guru memperlihatkan gambar serta kalimat dibawah gambar, kemudian guru harus menempelkan di papan tulis menempelkan di papan tulis, kemudian guru menyampaikan makna dari gambar harus jelas dan mudah dipahami anak sehingga anak memahami dan memperhatikan penjelasan guru, aspek guru meminta menyusun kalimat sederhana dalam struktur lengkap, memberikan kesempatan kepada anak secara mandiri untuk menyusun kalimat sederhana dalam struktur lengkap, guru membagi anak menjadi kelompok, dan memberikan kesempatan kepada kelompok untuk bekerjasama dalam kelompok untuk menyusun kalimat sederhana dalam struktur lengkap. Sehingga perlunya perbaikan aktivitas guru pada pertemuan berikutnya.

\section{Aktivitas Anak}

Penelitian ini akan dilanjutkan pada siklus II untuk lebih meningkatkan aktivitas anak, guru juga akan menjadi berusaha menjadi fasilitator yang baik untuk memotivasi siswa supaya aspek keberanian, kerjasama, ketepatan dapat tercapai dengan lebih baik lagi. Guru harus 
lebih memotivasi anak untuk meningkatkan antusias dan keberanian anak. Guru harus lebih menanamkan kepada anak pentingnya saling bekerjasama dan saling membantu dengan teman kelompok. Pentingnya guru berperan sebagai teman bagi anak pada saat proses pembelajaran sehingga anak tidak merasa canggung dalam pelaksanaan pembelajaran.

3. Hasil Pengembangan

Hasil pengembangan bahasa pada siklus I pertemuan 1 ketuntasan klasikal $43 \%$ belum memenuhi kriteria yang telah ditentukan. Pada pertemuan 2 mengalami peningkatan $50 \%$, hasil yang diperoleh belum mencapai hasil yang diharapkan, jika mencapai minimal BSH serta klasikal $80 \%$ siswa mendapat nilai berkembang sesuai harapan $(\mathrm{BSH}=$ bintang ***). Penelitian ini akan dilanjutkan lagi pada siklus II. Untuk menjadikan hasil pengembangan yang lebih optimal lagi, peneliti melaksanakan dan mempelajari model pembelajaran dengan tipe media visual dengan lebih baik lagi dengan berusaha sebaik mungkin membimbing dan mengarahkan ketika menyusun kalimat sederhana, guru dalam penyampaian materi akan berperan sebagai teman anak sehingga anak terdorong untuk memperhatikannya, menjadi fasilitator anak untuk mengembangkan aspek-aspek perkembangannya, guru harus menyampaikan materi yang lebih jelas kepada anak pada pertemuan berikutnya yang akan dijadikan sebagai soal evaluasi sehingga ketuntasan individual dan klasikal dapat tercapai.

\section{Pelaksanaan Tindakan Kelas Siklus II Pertemuan I}

1. Aktivitas guru

Hasil Aktivitas Pembelajaran Guru

\begin{tabular}{|c|c|c|c|c|c|}
\hline \multirow[b]{2}{*}{$\begin{array}{l}\mathbf{N} \\
\mathbf{O}\end{array}$} & \multirow[b]{2}{*}{$\begin{array}{l}\text { ASPEK YANG } \\
\text { DIAMATI }\end{array}$} & \multicolumn{4}{|c|}{ SKOR } \\
\hline & & 1 & 2 & 3 & 4 \\
\hline \multicolumn{6}{|c|}{ KEGIATAN PEMBELAJARAN } \\
\hline 1 & $\begin{array}{lr}\text { Guru } & \text { menyiapkan } \\
\text { alat/media } & \text { untuk } \\
\text { pembelajaran } & \end{array}$ & & & & $\sqrt{ }$ \\
\hline 2 & $\begin{array}{l}\text { Guru menyampaikan } \\
\text { tujuan pembelajaran yang } \\
\text { akan dipelajari }\end{array}$ & & & $\sqrt{ }$ & \\
\hline 3 & $\begin{array}{l}\text { Guru memperlihatkan } \\
\text { gambar serta kalimat } \\
\text { dibawah gambar lalu } \\
\text { menempelkan di papan } \\
\text { tulis. }\end{array}$ & & & & $\sqrt{ }$ \\
\hline 4 & $\begin{array}{l}\text { Guru menyampaikan } \\
\text { tentang makna dari gambar } \\
\text { tersebut. }\end{array}$ & & & & $\sqrt{ }$ \\
\hline 5 & $\begin{array}{l}\text { Guru meminta anak } \\
\text { menyusun } \\
\text { sederhana pada struktur } \\
\text { lengkap yang kata-katanya } \\
\text { diacak. }\end{array}$ & & & & $\sqrt{ }$ \\
\hline 6 & $\begin{array}{lr}\text { Guru } & \text { membagi anak } \\
\text { menjadi } & \text { kelompok, }\end{array}$ & & & $\sqrt{ }$ & \\
\hline
\end{tabular}




\begin{tabular}{|c|l|l|l|l|}
\hline $\begin{array}{l}\text { masing-masing kelompok } \\
\text { bekerjasama dalam } \\
\text { menyusun kalimat pada } \\
\text { struktur lengkap }\end{array}$ & $\mid$ & & \\
\hline TOTAL SKOR & $\mathbf{2 2}$ \\
\hline KRITERIA & SANGAT \\
& BAIK \\
\hline
\end{tabular}

\section{Aktivitas Anak}

perkembangan aktivitas anak pada aspek keberanian, kerjasama, ketepatan melalui model pembelajaran media visual mengalami peningkatan, rata-rata kelompok memperoleh persentase $89 \%$ dengan katagori sangat aktif. Anak sangat bersemangat pada pelaksanaan kegiatan sehingga aktivitas pembelajaran mengalami peningkatan menjadi sangat aktif. Hal ini menunjukkan bahwa aktivitas anak mencapai indikator yang ditetapkan yaitu 80 $\%$. Penelitian akan dilanjutkan pada pertemuan berikutnya agar aktivitas anak lebih aktif lagi.

\section{Hasil Pengembangan}

Hasil pengembangan klasikal pengembangan bahasa untuk siklus II Penelitian Tindakan Kelas ini dapat digambarkan pada grafik berikut:

\author{
Diagram Lingkaran Hasil \\ Pengembangan
}

Pelaksanaan Tindakan Kelas Siklus II

\section{Pertemuan II}

\section{Hasil Observasi}

1. Aktivitas Guru

Hasil Aktivitas Pembelajaran Guru

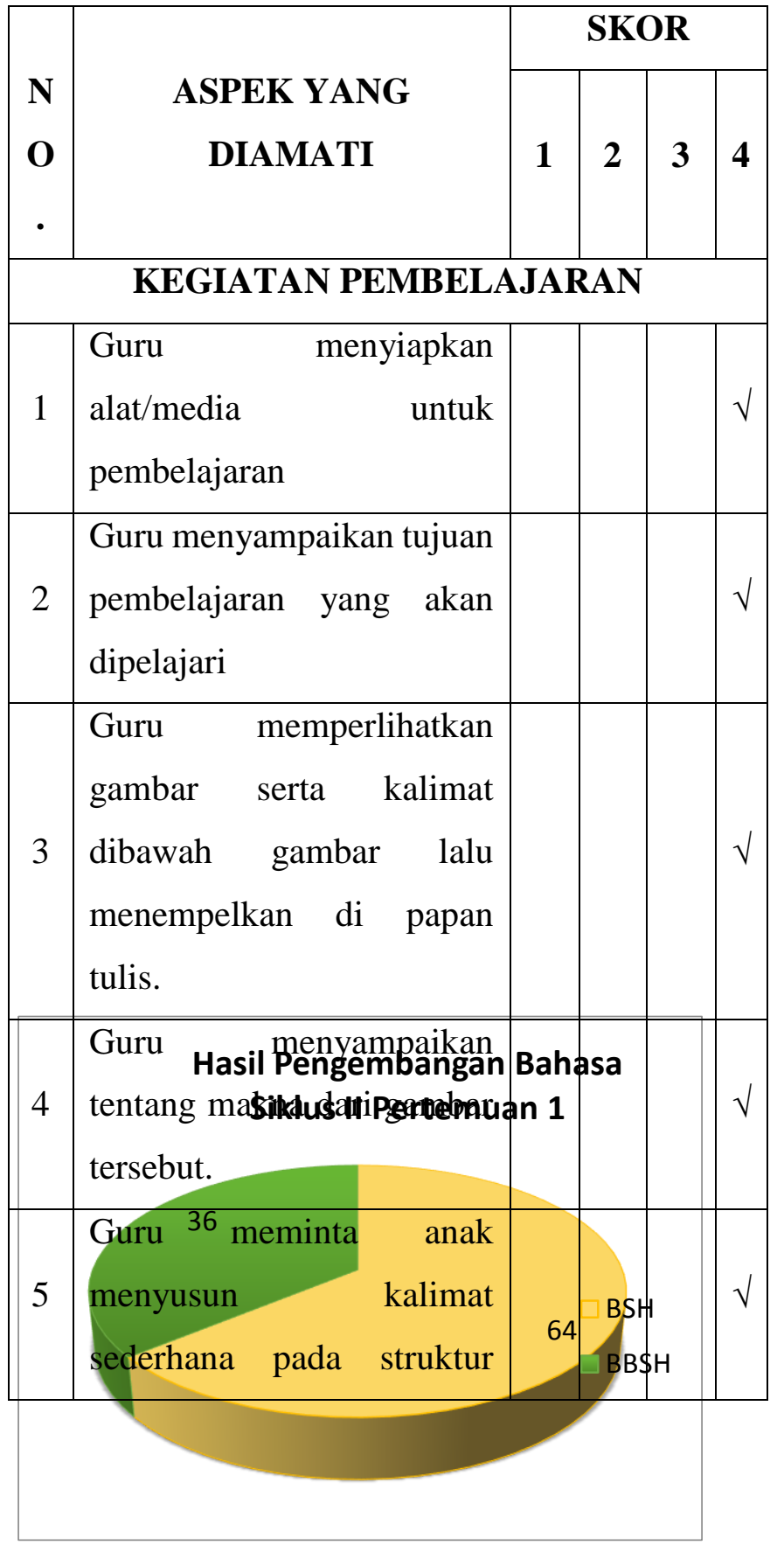




\begin{tabular}{|c|l|l|l|l|l|}
\hline & \multicolumn{2}{|l|}{$\begin{array}{l}\text { lengkap yang kata-katanya } \\
\text { diacak. }\end{array}$} \\
\hline $\begin{array}{l}\text { Guru membagi anak } \\
\text { menjadi kelompok, masing- } \\
\text { masing krompok } \\
\text { bekerjasama dalam } \\
\text { menyusun kalimat pada } \\
\text { struktur lengkap }\end{array}$ & & & & & \\
\hline TOTAL SKOR & & & \\
\hline KRITERIA & SANGAT \\
\hline & BAIK \\
\hline
\end{tabular}

\section{Aktivitas Anak}

perkembangan aktivitas anak pada aspek keberanian, kerjasama, ketepatan melalui model pembelajaran media visual mengalami peningkatan, rata-rata kelompok memperoleh persentase $96 \%$ dengan katagori sangat aktif. Hal ini menunjukkan bahwa aktivitas anak mencapai indikator yang ditetapkan yaitu 80 $\%$. Aktivitas anak secara berkelompok mengalami peningkatan.

\section{Hasil Pengembangan}

Hasil pengembangan klasikal pengembangan bahasa untuk siklus II Penelitian Tindakan Kelas ini dapat digambarkan pada grafik berikut:

\section{Diagram Lingkaran Hasil Pengembangan}

\section{Refleksi Siklus II}

1. Aktivitas Guru

Kegiatan pembelajaran yang dilakukan guru sudah berjalan efektif, dengan dilaksanakannya perbaikan-perbaikan yang telah direncanakan pada refleksi siklus I, hal ini terlihat dari aspek yang diobservasi sudah sepenuhnya dilaksanakan guru dengan sangat baik dan optimal. Pada siklus II pertemuan 1 aktivitas guru telah terlaksana memperoleh skor 22 dengan kriteria sangat baik. Pada siklus II pertemuan 2 aktivitas guru telah terlaksana memperoleh skor 24 dengan kriteria sangat baik. Hal ini menunjukkan keberhasilan aktivitas yang dilaksanakan guru yang sesuai indikator jika mencapai skor 19-24 dengan katagori sangat baik.

\section{Aktivitas Anak}

Pada siklus II pertemuan 1 aktivitas anak-anak nilai rata-rata yang diperoleh adalah $89 \%$ dengan kategori sangat aktif. Pada pertemuan 2 aktivitas anak memperoleh persentase $96 \%$ dengan katagori sangat aktif. Hal ini berarti aktivitas anak telahs IIPentedpaian 2indikator keberhasilan $80 \%$. Berd@sarkan data hasil pengamatan observer, aktivitas anak juga menunjukkan adanya perkembangan terhadaa pembelajaran yang disampaikan sebab delisis beberapa aspek telah menunjukkan adanya 
perbaikan yang diharapkan. dengan kategori sangat aktif dan sudah mencapai indikator keberhasilan yang diharapkan (memuaskan).

\section{Hasil Pengembangan.}

Hasil pengembangan yang diperoleh sudah mencapai indikator keberhasilan yang diharapkan yaitu $100 \%$ tuntas mendapatkan $\geq$ (***) artinya berkembang sesuai harapan, berdasarkan dari temuan data diatas dapat dinyatakan pembelajaran dengan menerapkan model media visual sudah mencapai target atau indikator-indikator yang telah ditetapkan sebelumnya.

\section{Pembahasan}

Berdasarkan hasil Penelitian Tindakan Kelas yang dilaksanakan pada siklus I dua kali pertemuan dan siklus II dua kali pertemuan, upaya Talking Stick dalam proses pembelajaran di kelompok A Paud Terpadu Darunnajah Martapura Kabupaten Banjar baik aktivitas guru, aktivitas anak, dan hasil pengembangan hasil belajar selalu mengalami peningkatan pada setiap kali pertemuan. Hasil dari faktor yang diteliti meliputi observasi aktivitas guru, observasi aktivitas anak, dan hasil belajar anak dijelaskan sebagai berikut:

\section{Aktivitas Guru}

Berdasarkan ketercapaian data aktivitas guru, maka penelitian tindakan kelas ini dikatakan berhasil dengan menggunakan langkah-langkah model pembelajaran Talking Stick. Guru berupaya agar siswa lebih termotivasi lagi dalam mengikuti pelajaran guna meningkatkan kreativitas siswa dan hasil belajarnya. Hal ini sesuai dengan pendapat Gibbs yang menyatakan bahwa kreativitas dapat dikembangkan dengan memberi kepercayaan, komunikasi yang bebas, pengarahan diri, dan pengawasan yang tidak terlalu ketat. Dari pernyataan Gibbs ini dapat menguatkan bahwa penerapan model kooperatif dalam pembelajaran dapat meningkatkan aktivitas, kreativitas dan hasil belajar siswa (Mulyasa, 2009: 164).

Model pembelajaran Talking Stick yang digunakan dalam penelitian ini merupakan salah satu tipe dalam pembelajaran kooperatif yang dapat meningkatkan motivasi dan kreativitas juga dapat meningkatkan hasil belajar siswa. Hal ini sesuai dengan pendapat Trianto (2010: 59) yaitu para ahli telah menunjukkan bahwa pembelajaran kooperatif dapat meningkatkan kinerja siswa dalam tugastugas akademik, unggul membantu siswa memahami konsep yang sulit dan membantu sisiwa menumbuhkan kemampuan berfikir kritis.

Guru sebagai pengajar, guru sebagai pembimbing untuk melaksanakan merencanakan tujuan dan mengidentifikasi kompetensi yang hendak dicapai, guru harus melihat keterlibatan peserta didik dalam 
pembelajara, dan peserta didik melaksanakan kegiatan belajar itu tidak hanya secara jasmaniah, tetapi mereka harus terlibat secara psikologis (Yelon, 2010 : Online).

\section{Aktivitas Anak}

Hasil penelitian Tindakan Kelas (PTK) dalam pembelajaran dengan menggunakan model pembelajaran Talking Stick di kelompok A Paud Terpadu Darunnajah siswa lebih aktif dalam belajar, siswa dapat memahami materi dengan cepat juga dapat mendorong siswa untuk berani, saling bekerjasama dan tepat dalam mengulang kalimat sederhana.

Talking Stick merupakan suatu model pembelajaran kooperatif yang dapat meningkatkan motivasi dan kreativitas juga dapat meningkatkan hasil belajar siswa. pembelajaran dengan model Talking Stick ini mendorong peserta didik untuk berani mengemukakan pendapat (Suprijono, 2009: 109). Meurut Huda (2011: 66) manfaat besar Talking Stick akan memperoleh hasil belajar yang lebih tinggi, motivasi yang lebih besar untuk belajar, dan meningkatnya rasa penerimaan sisa terhadap teman-temannya yang berasal dari latar belakang ras juga etnik yang berbeda-beda.

Melalui kegiatan bermain anak dapat melatih kemampuan bahasanya dengan cara: mendengarkan beraneka bunyi, mengucapkan suku kata atau kata, memperluas kosa kata, berbicara sesuai dengan Tata Bahasa
Indonesia, dan sebagainya (Moeslichatoen, 2004: 32-33).

Gibbs dalam Mulyasa (2009: 164) menyatakan aktivitas dan kreativitas siswa dapat dikembangkan dengan memberi kepercayaan, komunikasi yang bebas, pengarahan diri dan pemngawasan yang tidak terlalu ketat. Serta berlandaskan pendapat Lazanov, yang menyatakan bahwa tugas pertama seorang guru ialah mendorong siswanya dalam belajar (Djanali, 2007: 33).

\section{Hasil Pengembangan Bahasa}

Berdasarkan

hasil pengembangan anak pada siklus I dan siklus II dapat disimpulkan bahwa mengalami peningkatan hasil pengembangan bahasa dalam menyusun kalimat sederhana. Begitu pula jika dibandingkan terhadap hasil pengembangan anak sebelum diadakan tindakan perbaikan, terlihat ada peningkatan hasil pengembangan yang sangat signifikan. Peningkatan hasil pengembangan tersebut dikarenakan guru telah menggunakan model pembelajaran yang tepat sesuai dengan karakteristik anak dan penggunaan media visual. Penggunaan media visual ternyata telah memberikan pengalaman langsung pada anak dan mereka dapat belajar melalui penglihatannya, hal ini sesuai yang dikatanan oleh Zaman (2009) bahwa menurut penelitian anak dapat pengetahuan dalam belajar melalui visualnya sebanyak $75 \%$.

Meningkatnya hasil pengembangan anak karena anak senang dan termotivasi dalam 
mengikuti kegiatan pembelajaran, karena pembelajaran tidak melupakan karakteristik belajar anak yang konkrit, hierarkis, dan integratif (Anonim,2007: Online). Hal ini didukung oleh teori belajar konstruktivis bahwa seseorang tidak akan menyerap pengetahuan dengan pasif. Untuk membangun suatu pengetahuan baru peserta didik akan menyesuaikan informasi baru atau pengetahuan yang disampaikan guru dengan pengetahuan atau pengalaman yang telah dimilikinya melalui interaksi sosial dengan peserta didik lain atau dengan gurunya
(Yulaelawati, 2009). Pendapat tersebut sejalan dengan pendapat Suprijono (2011) yang menyatakan bahwa belajar yang baik adalah jika peserta didik terlibat secara pribadi dalam pengalaman belajarnya, karenanya pengetahuan harus ditemukan peserta didik sendiri agar mereka memiliki arti, peserta didik juga harus memiliki komitmen terhadap belajar dan berusaha secara aktif untuk mencapainya dalam kerangka kerja tertentu (Andayani, 2007: online) 


\section{DAFTAR PUSTAKA}

Ahmad Susanto, 2011. Perkembangan Anak Usia Dini. Jakarta. Prenada Media Group

Arikunto, Suharsimi. (2010). Prosedur Penelitian: Suatu Pendekatan Praktik. Jakarta: Rineka Cipta.

Anonim, 2010. Perkembangan Bahasa Anak. http:// bayi balita.com/2010/07/Perkemangan bahasa - anak/

Asrori,2008. Psikologi Pembelajaran. Bandung. Wacana Prima

Carol Seefeldt \& Barbara A. Wasik, 2008. Pendidikan Anak Usia Dini. Jakarta. Indeks

Daryanto. (2012). Penelitian Tindakan Kelas. Jakarta: PT. Prestasi Pustakarya

Departemen Pendidikan Nasional, 2001. Program Kegiatan Pembelajaran untuk Kelompok Bermain dan Penitipan Anak. Jakarta. Depdiknas

Depdiknas. 2005. Kurikulum 2004 Standar Kompetensi TK dan RA. Jakarta. Dirjendikdasmen

Hasbullah. (2012). Dasar-Dasar Ilmu Pendidikan. Jakarta: PT. Rajagrafindo Persada

http://blogspot.com/2010/11/model-picture-and-picture.html//

http://erwan68.wordpress.com/2008/05/model-dan-peran-guru-dalam-pembelajaran//

http://www.infoanak.com/tag/Perkembangan-bahasa-anak//

$\underline{\text { http://www.lalf.edu/ }}$

http://tpcommunityos.blogspot.com/2008/05/stategi-memanfaatkan-media-gambar.html//

Ibrahim, dkk,2000. Pembelaaran Kooperatif. Surabaya. Universitas Press

Iskandar, 2011. Penelitian Tindakan Kelas. Jakarta. Gaung Persada

Isjoni. (2012). Pembelajaran Kooperatif Meningkatkan Kecerdasan Komunikasi Antar Peserta Didik. Yogyakarta: Pustaka Pelajar

Maulina,Dita, 2000.Perkembangan Bahasa Anak. Jakarta. Rieneka

Martinis Yamin \& Jamilah Sabri Sanan, 2010. Panduan Pendidikan Anak Usia Dini. Jakarta. Gaung Persada.

Martini Jamaris, 2005. Perkembangan dan Pengembangan Anak Usia Taman Kanak-Kanak. Jakarta. Grasindo

Munandra, Utami. 2000. Kreatifitas dan Keberbakatan Strategi Mewujudkan Potensi Kreatif dan Bakat. Jakarta. PT. Gramedia Utami 
Nurbiana Dhieni dkk, 2007.Metode Pengemangan Bahasa. Jakarta. Universitas Terbuka

Patmonodewo, S. 2002. Pendidikan Anak Prasekolah. Jakarta. PT.Reineka Cipta

Pratisti,Wiwien,Dinar.2008. Psikologi Anak Usia Dini. Jakarta PT Indeks

Santoso, S. 2002. Pendidikan Anak Usia Dini. Jakarta. Citra Pendidikan

Suwandi, Sarwiji, 2011. Penelitian Tidakan Kelas. Surakarta. Yuma Pustaka

Susilo, 2009. Penelitian Tindakan Kelas . Yogyakarta. Pustaka Book Publisher

Siti Aisyah.2008. Perkembangan dan Konsep Dasar Pengembangan Anak Usia Dini. Jakarta. Universitas Terbuka

Suriansyah, Ahmad, dkk. (2013). Panduan Penulisan Karya Ilmiah Program PG-PAUD dan PGSD Universitas Lambung Mangkurat. Banjarmasin: FKIP UNLAM.

Trianto,2011. Desain Pengembangan Pembelajaran Tematik Bagi Anak Usia Dini TK/RA \& Anak Usia Kelas Awal SD/MI. Jakarta.Kencana Prenada Media Group

Tim Instruktur,2010. Pendidikan dan Latihan Profesi Guru. Banjarmasin. Universitas Lambung Mangkurat

Whandi,2010. Perkembangan Berbicara pada Anak Usia Dini : http://Whandi.net/Perkembangan-berbicara-bahasa-pada-anak-anak-usia-dini-html//

Yuliani Nurani Sujiono, 2007. Buku Ajar Konsep Dasar Pendidikan Anak Usia Dini. UNJ 